\title{
Research on the Impact of Dividend Policy on the Performance of Listed Companies' Market Value Management
}

\author{
Yan-liang ZHANG*, Bing-qian HUO \\ School of Finance \\ Shandong University of Finance and Economics \\ Jinan China
}

\author{
Le-ya ZHANG \\ Stirling Management School \\ University of Stirling \\ Stirling, Scotland, United Kingdom
}

\begin{abstract}
To explore the impact of different dividend policies on the market value management of listed companies, the MVM value obtained by reducing the dimensionality of the market value management evaluation index (MVM) system is used as the proxy variable of the market value management, and then the empirical test is carried out by using the propensity score value matching method and the panel regression model. The results show that the implementation of the cash dividend policy does not play a significant role in the market value management level, and the stock dividend policy will have a significant positive impact.
\end{abstract}

Keywords-Dividend Policy; Market Value Management; Stock dividend; Cash dividend

\section{INTRODUCTION}

The reform of non-tradable shares makes the market value of enterprises more and more concerned, and the concept of market value management comes into being. However, the effectiveness of China's capital market is relatively low, and the intrinsic value of enterprises cannot be fully reflected in the market. At this time, the sustainable and stable growth of enterprise value and market value through market value management has become a long-term goal of listed companies. As one of the core financial policies of listed companies, dividend policy is of great significance for the sustainable and stable growth of market value of listed companies. However, China's securities market started late, the market operation mechanism is not mature, the equity structure of listed companies is not reasonable, and the information disclosure is not sufficient, which leads to the separation of dividend policy formulation from the actual operation of the company. This paper makes an in-depth study on the relationship between dividend policy and market value management of listed companies in order to achieve the goal of market value management through the adjustment of dividend policy.

\section{REVIEW OF LITERATURE}

\section{A. Market Value Management}

Shi Guang-yao (2007) [1], believed that market value management is a kind of strategic management behavior, which should take three aspects of shareholders, stock price and capital stock as the entry point, and realize the stable and sustainable growth of enterprise value and market value as the ultimate goal, and established the market value management evaluation index (MVM) system of listed companies (Shi Guang-yao, 2008 [2]). Zhang Ji-jian and Miao Qing (2010) [3] pointed out that in emerging markets, market value management is not simply equivalent to value management. Compared with the latter, market value management has two more links of value operation and value realization, which are closely linked with each other.

\section{B. Dividend Policy}

Chen Hong and Wu Wei-hua (2011) [4] believe that whether the listed companies make dividend distribution is determined to some extent by the concentration of equity structure. Shao Jun (2004) [5] found that the formulation of dividend policy is determined by the profitability of the enterprise in that year, but the size of the company has no significant effect on the dividend policy.

\section{The Impact of Dividend Policy on Market Value Management}

Xu Shi-zhi and Zhang Zheng (2007) [6] use the event study method to empirically conclude that the dividend policy implemented by China's listed companies has a strong signal transmission function, which is conducive to improving the information environment of investors and reducing pricing bias Juan (2017) [7] found that companies with higher level of dividend payment have higher enterprise value, but too high level of dividend payment will also have an adverse impact on enterprise value. Based on the previous studies, this paper extends to explore the impact of dividend policy on market value management, which may be the innovation of this paper.

\section{THE INFLUENCE MECHANISM OF DIVIDEND POLICY ON MARKET VALUE MANAGEMENT}

\section{A. Industrial End: the Angle of Enterprise Value Creation}

The separation of asset ownership and right to use will produce principal-agent relationship. In order to prevent the agent from damaging their own interests, the principal needs to 
conduct additional supervision. The resulting cost and loss efficiency constitute the agent cost. Ghose (2004) [8] found that the cash dividend policy can reduce the retained earnings by paying cash dividend, thus reducing the agency cost between management and shareholders. Liu Yin-guo (2014) [9] conducted research on China's market, and also confirmed that cash dividends can reduce agency costs.

Equity incentive also has some development in China. The issuance of stock dividends increases the stock holding of agents, improves the correlation between their own interests and the market value of the company, and plays a positive role in reducing agency costs.

\section{B. Capital End: the Angle of Realizing Enterprise Value}

In the system of irrational financial research, individual stock price will be affected by information and noise. The theory circles at home and abroad generally start from the information asymmetry theory, pointing out that the information asymmetry phenomenon is the reason why the internal value of the company does not match the market value. The dividend policy is a way to open the internal information to the market. The listed companies can pass the information about the company's operation and future profitability to the market through the choice of dividend policy. The research of Varun (2014) [10] also confirmed that dividend policy can transmit information, and the company can reduce the impact of information asymmetry by paying dividends.

To sum up, the dividend policy can not only help enterprises to improve their value creation ability from the industrial end by reducing agency costs, but also alleviate the problem of information asymmetry, transfer enterprise value from the capital end, and promote the matching of enterprise market value and value, so as to achieve the goal of market value management.

\section{VARIABLE AND MODELS}

In order to study the impact of different dividend policies on the market value management of listed companies, this paper empirically analyzes cash dividends and stock dividends, and puts forward the following research hypotheses:

H1: the distribution of stock dividends can promote the improvement of market value management level of listed companies

$\mathrm{H} 2$ : paying cash dividends is conducive to improving the market value management of listed companies;

H3: the level of stock dividend payment is positively related to market value management;

H4: cash dividend payment level is positively related to market value management.

\section{A. Variable Description}

Interpreted variable. This paper uses the market value management evaluation index (MVM) system established by the market value management research center of China's listed companies to measure the market value management level, uses the factor analysis method to reduce its dimension, and obtains the comprehensive factor score MVM. The larger the MVM value, the higher the market value management level.

Explain variables. In this paper, two groups of virtual variables D1 and D2 are constructed, which are respectively taken as 1 when the company issues stock dividends and cash dividends, and 0 in other cases.

Control variables. In order to reduce the potential impact of endogeneity on the research results, this paper selects the indicators reflecting the company level information as the control variables based on the above explanatory variables. See Table I for specific variable description and definition.

TABLE I. VARIABLE Symbols AND MEANings

\begin{tabular}{|c|c|c|c|}
\hline Variable type & Variable name & Variable symbols & Definition \\
\hline $\begin{array}{c}\text { Interpreted } \\
\text { variable }\end{array}$ & $\begin{array}{c}\text { Market value management level of } \\
\text { listed companies }\end{array}$ & MVM & Factor analysis score \\
\hline \multirow{2}{*}{$\begin{array}{c}\text { Explain } \\
\text { variables }\end{array}$} & Virtual variable of stock dividend & $\mathrm{D} 1$ & $\begin{array}{c}\text { The value of issued stock dividend is } \\
\text { 1,otherwise it is 0 }\end{array}$ \\
\cline { 2 - 4 } & Virtual variable of cash dividend & $\mathrm{D} 2$ & $\begin{array}{c}\text { The value of cash dividend paid is } \\
\text { 1,otherwise it is 0 }\end{array}$ \\
\cline { 2 - 4 } & Share delivery ratio & PERSPT & Held shares \\
\cline { 2 - 4 } & Dividend ratio & ATPERDIV & Cash dividends/Share price \\
\hline \multirow{2}{*}{$\begin{array}{c}\text { Control } \\
\text { variables }\end{array}$} & Company Size & SIZE & Natural logarithm of total assets \\
\cline { 2 - 4 } & Capital Structure & DAR & Total liabilities/Total assets \\
\cline { 2 - 4 } & P / E ratio & PE & Ending share price/Ending earnings per share \\
\hline
\end{tabular}

adopted by each company, the samples are divided into three

\section{B. Sample Selection and Data Source}

In this paper, all A-share listed companies in China from January 1, 2013 to December 31, 2018 are selected as the research samples, excluding the listed companies in the financial industry and the samples with missing relevant variables, and according to the different dividend policies parts: stock dividend, cash dividend and non-dividend. Table II shows the descriptive statistical indicators for each variable. 
TABLE II. DESCRIPTIVE STATISTICS

\begin{tabular}{|c|c|c|c|c|c|c|}
\hline variable & $\mathbf{N}$ & mean & sd & min & max & p50 \\
\hline MVM & 5418 & 0.093 & 0.402 & -7.193 & 17.29 & 0.022 \\
\hline D1 & 5418 & 0.028 & 0.164 & 0 & 1 & 0 \\
\hline D2 & 5418 & 0.809 & 0.393 & 0 & 1 & 1 \\
\hline PERSPT & 5418 & 0.009 & 0.068 & 0 & 1.500 & 0 \\
\hline ATPERDIV & 5418 & 0.112 & 0.219 & 0 & 6.787 & 0.050 \\
\hline SIZE & 5418 & 22.061 & 1.225 & 15.979 & 27.962 & 21.915 \\
\hline DAR & 5418 & 0.401 & 0.202 & 0.0090 & 0.987 & 0.385 \\
\hline PE & 5418 & 226.2 & 5759 & 1.070 & 7280 & 57.49 \\
\hline
\end{tabular}

According to table II, the average value of MVM score is only 0.093 , the minimum value is as low as -7.193 , and the maximum value is 17.29 , indicating that there are huge differences in market value management level between different listed companies, and the overall average level is low, so it is of great significance to adjust dividend policy to promote market value management. At the same time, the average value of D1 is 0.028 , which means that the listed companies that issue stock dividends only account for $2.8 \%$ of the sample number, while the average value of D2 is 0.809 . Compared with that, the dividend distribution in the form of cash dividend is more easily adopted by the listed companies. In the same way, the average value of stock dividend is 0.009 compared with PERSPT and 10.3 percentage points less than that of ATPERDIV, which indicates that even the companies that make stock dividend distribution control the stock dividend rate.

\section{Model Building}

According to the above variable definitions and assumptions, the regression model of panel data is constructed as follows:

$$
\begin{aligned}
& M V M=\alpha+\beta_{1} D_{1}+\beta_{2} S I Z E+\beta_{3} D A R+\beta_{4} P E+\varepsilon_{i, t} \\
& M V M=\alpha+\beta_{1} D_{2}+\beta_{2} S I Z E+\beta_{3} D A R+\beta_{4} P E+\varepsilon_{i, t} \\
& M V M=\alpha+\beta_{1} P E R S P T+\beta_{2} S I Z E+\beta_{3} D A R+\beta_{4} P E+\varepsilon_{i, t} \\
& M V M=\alpha+\beta_{1} A T P E R D I V+\beta_{2} S I Z E+\beta_{3} D A R+\beta_{4} P E+\varepsilon_{i, t}
\end{aligned}
$$

\section{EMPIRICAL RESULTS AND ANALYSIS}

In this paper, all the control variables in the model are added to the logit regression. Then, on the premise that the samples support the hypothesis of common support and parallelism, the PSM model is used to match the companies that pay stock or cash dividends with the companies that do not pay dividends, and the control samples that eliminate the systematic differences of companies are obtained, which is the main research sample of this paper.

\section{A. The Influence of Stock Dividend on the Management Level of Market Value}

The regression estimation of model (1) is carried out by using the full sample and the sample matched by PSM respectively, and the results are shown in Table III. Among the full sample regression results, the core variable D1 coefficient is $0.093, \mathrm{t}$ value is 3.29 , and is significant at the statistical level of $1 \%$, indicating that the issuance of stock dividends can significantly improve market value management; in the PSM sample regression results, D1 coefficient is 0.084 , although the coefficient of the whole sample group is reduced, $t$ value is also reduced, 3.04, but still $1 \%$ of the statistical water It is obvious on the level. It shows that after removing the systematic differences of different companies, stock dividend still has a significant positive marginal effect on improving the market value management of listed companies, assuming $\mathrm{H} 1$ is tenable.

TABLE III. The Regression Results of Stock Dividend Policy AND MARKET VALUE MANAGEMENT LEVEL

\begin{tabular}{|c|c|c|}
\hline & Whole Sample & PSM Sample \\
\hline & $\boldsymbol{M V M}$ & $\boldsymbol{M V M}$ \\
\hline D1 & $0.093^{* * *}$ & $0.084^{* * *}$ \\
\hline & $(3.29)$ & $(3.04)$ \\
\hline SIZE & $0.005^{* * *}$ & $0.003^{* * *}$ \\
\hline & $(9.38)$ & $(4.47)$ \\
\hline DAR & $0.104^{* *}$ & 0.123 \\
\hline & $(2.42)$ & $(1.16)$ \\
\hline PE & 0.000 & -0.000 \\
\hline & $(0.52)$ & $(-1.41)$ \\
\hline cons & 0.043 & -0.012 \\
\hline & $(1.20)$ & $(-0.13)$ \\
\hline Observations & 5395 & 294 \\
\hline Adjusted $\mathrm{R}^{2}$ & 0.291 & 0.459 \\
\hline
\end{tabular}

\section{B. The Influence of Cash Dividend on the Management Level} of Market Value

Using the dividend policy sample to regress the model (2), the results show that: the cash dividend does not significantly improve the market value management of listed companies; and the cash dividend policy does not effectively improve the market value management, assuming that $\mathrm{H} 2$ is not tenable.

\section{The influence of stock dividend payment rate on market value management}

The regression estimation of model (3) is carried out by using the whole sample and the sample matched by PSM, and 
the results are shown in Table IV. In the regression results of the two sample groups, the coefficient of PERSPT is positive, which is significant at the level of 5\%, indicating that the ratio of shares to market value management has a significant positive impact, assuming $\mathrm{H} 3$ holds.

TABLE IV. The REgRESSION RESUlts OF STOCK DividEND POLICY AND MARKET VALUE MANAGEMENT LEVEL

\begin{tabular}{|c|c|c|}
\hline & Whole Sample & PSM Sample \\
\hline & $\boldsymbol{M V M}$ & $\boldsymbol{M V M}$ \\
\hline PERSPT & $0.193^{* * *}$ & $0.144^{* *}$ \\
\hline & $(3.54)$ & $(2.39)$ \\
\hline SIZE & $0.001^{* * *}$ & $0.001^{* * *}$ \\
\hline & $(9.38)$ & $(4.42)$ \\
\hline DAR & $0.103^{* *}$ & 0.093 \\
\hline & $(2.41)$ & $(0.86)$ \\
\hline PE & 0.001 & -0.001 \\
\hline & $(0.52)$ & $(-1.37)$ \\
\hline _cons & 0.045 & 0.022 \\
\hline Observations & $(1.24)$ & $(0.24)$ \\
\hline Adjusted $\mathrm{R}^{2}$ & 5395 & 294 \\
\hline
\end{tabular}

D. The Influence of Cash Dividend Payment Rate on Market Value Management

Table V shows the regression results of two sample groups for model (4). In the regression results of the two sample groups, the coefficient of ATPERDIV is significantly positive at the level of $1 \%$, indicating that there is also a significant positive correlation between cash dividend payment rate and market value management, assuming H4 holds.

TABLE V. REGRESSION RESUlts OF CASH DiVIDEND PAYMENT RATE AND MARKET VALUE MANAGEMENT LEVEL

\begin{tabular}{|c|c|c|}
\hline & Whole Sample & PSM Sample \\
\hline & $\boldsymbol{M V M}$ & $\boldsymbol{M V M}$ \\
\hline ATPERDIV & $0.498^{* * *}$ & $0.497^{* * *}$ \\
\hline & $(10.33)$ & $(10.28)$ \\
\hline SIZE & $0.001^{* * *}$ & $0.001^{* * *}$ \\
\hline & $(11.05)$ & $(11.00)$ \\
\hline DAR & $0.157^{* * *}$ & $0.161^{* * *}$ \\
\hline & $(3.82)$ & $(3.54)$ \\
\hline PE & 0.002 & 0.001 \\
\hline & $(0.75)$ & $(0.75)$ \\
\hline cons & 0.016 & 0.015 \\
\hline & $(0.46)$ & $(0.43)$ \\
\hline Observations & 5395 & 5227 \\
\hline Adjusted R & 0.348 & 0.348 \\
\hline
\end{tabular}

\section{CONCLUSION}

The conclusions are as follows:

Paying cash dividends does not significantly improve the market value management of listed companies, but there is a significant positive correlation between the market value management and the cash dividend payment rate, so properly increasing the dividend ratio is conducive to the improvement of the market value management level, at the same time, if the dividend payment rate is lower than the expectation of investors, it may also lead to the decline of market value management.

Dividend distribution in the form of stock can significantly improve the level of market value management. Similarly, there is a significant positive correlation between stock dividend payout rate and market value management, so it is more conducive to achieve market value management objectives to reasonably distribute stock dividends and appropriately improve the payment level.

\section{REFERENCES}

[1] Shi Guang-yao, Shao Yong-liang, "The era of market value management is coming quietly," [J]. Board of directors, 2007 (11): 41-45. (In Chinese).

[2] Shi Guang-yao, Liu Guo-fang, Liang Yan-jun, "Research on market value management evaluation of Chinese Listed Companies," [J]. Journal of management, 2008 (01): 78-87. (In Chinese).

[3] Zhang Ji-jian, Miao Qing, "Research on market value management of Chinese Listed Companies," [J]. Accounting research, 2010 (04): 82-88. (In Chinese).

[4] Chen Hong, Wu Wei-hua, "Equity structure, cash dividend policy and investor protection of Listed Companies," [J]. Research on financial development, 2011 (05): 62-69. (In Chinese).

[5] Shao Jun, "Empirical Study on cash dividends of Chinese Listed Companies," [J]. Productivity research, 2004 (12): 168-170. (In Chinese).

[6] Xu Shi-zhi, Zhang Zheng, "An Empirical Study on the connotation of dividend policy information of Listed Companies in China," [J]. International business (Journal of University of international economics and trade), 2007 (04): 42-47. (In Chinese).

[7] Juan Manuel San Martín Reyna, "Ownership structure and its effect on dividend policy in the Mexican context," [J]. Contaduría Y Administración, 2017, 62: págs.1199-1213.

[8] Anindya Ghose, "Capital inflows and investment in developing countries[J].2004

[9] Liu Ying-guo, Zhang Chen, Ruan Su-mei, "Study on agency cost control effect of cash dividend - Based on semi compulsory dividend," [J]. Audit and economic research, 2014,29 (05): 59-68. (In Chinese).

[10] Varun Dawar, "Dividends, Debt and Investment: Impact on Stock Prices-Evidence from Indian," [J]. Asia-Pacific Journal of Management Research and Innovation,2014,9(4):389-397. 